\title{
The Effect of Eisenia bicyclis Extracts on Antioxidant Activity and Serum Lipid Level in Ovariectomized Rats
}

\author{
Yong Soo Park and Mihyang Kim* \\ Department of Food and Nutrition, Silla University, Busan 617-738 Korea
}

Received September 11, 2012 /Revised October 23, 2012 /Accepted October 23, 2012

\begin{abstract}
Hormone replacement therapy (HRT) is an effective regimen that has been found to prevent these diseases in postmenopausal women. However, HRT is accompanied by an increased risk of unfavorable outcomes. This study was conducted to evaluate the effects of Eisenia Bicyclis extract on lipids in ovariectomized rats. Fifty 7-week-old female Sprague - Dawley rats were randomly assigned to four groups: sham-operated rats (SHAM), ovariectomized rats (OVX-CON), and ovariectomized rats that were treated with Eisenia bicyclis extracts. The extract-treated diets were fed to the rats for 6 weeks after operation. Antioxidant effects were measured by DPPH free radical scavenging activity. Antioxidant activity of the ethanol extract increased in a dose-dependent manner and was about $55.9 \%$ in a concentration of $100 \mathrm{\mu g} / \mathrm{ml}$. We measured the total cholesterol content, triglyceride content, HDL-cholesterol content, LDL-cholesterol content, atherosclerotic index, cardiac risk factor in serum, and anti-platelet aggregation and blood rheology. The total cholesterol and triglyceride concentration in serum increased for the OVX-control group, but supplementation with the E. bicyclis extract caused these factors to decrease. Notably, the serum LDL-cholesterol concentration in the OVX-EB200 group was significantly lower than the OVX-CON group. In addition, the blood passage times in rats that received the E. bicyclis extract were more rapid than the times in the untreated group (OVX-CON). Microscopic evaluation revealed that whole blood passed more smoothly through the microchannels in rats in the E. bicyclis extract supplement groups. Our results clarified the effects of E. bicyclis extract on serum lipid content in ovariectomized rats, and consequently we expect positive effects from providing E. bicyclis extract to postmenopausal women with cardiovascular disease.
\end{abstract}

Key words : Eisenia bicyclis, antioxidant activity, serum lipids, ovariectomized rats

\section{서 론}

폐경은 갱년기 중에 일어나게 되며, 폐경 여성의 경우 관상 동맥성 심장질환의 발병률이 급격히 증가하는 경향을 나타내 고 있다. 관상동맥 질환은 고혈압, 고지혈증, 당뇨, 흡연 등의 위험 요소와 관련된 질환으로 폐경 이후 또는 수술에 의한 그 위험도는 2.5 배 이상 큰 것으로 알려져 있다[23]. 폐경과 관련된 여성의 신체 · 심리적 증상을 완화하기 위해 호르몬 요법, 약물요법, 운동요법 및 식이요법이 권해지기도 하며, 호 르몬 보충요법은 안면홍조 완화와 골다공증의 치료와 예방에 효과가 있으며, 심혈관계질환을 30-50\% 감소시키는 것으로 보 고된 바 있다[9, 31]. 하지만 약물 요법으로 인한 에스트로겐 치료는 유방암의 위험률을 증가시킬 수 있으며, 장기간 사용 시에는 자궁내막암, 유방암, 혈전관련 혈관질환, 담낭질환, 고 혈압의 빈도를 증가시킬 수 있다[27]. 또한 미국 국립보건원 $(\mathrm{NIH})$ 의 연구를 비롯한 장기간의 추적연구에서 호르몬 보충

*Corresponding author

Tel : +82-51-999-5620, Fax : +82-51-995-5457

E-mail : mihkim@silla.ac.kr
요법이 유방암, 정맥혈전색전증 뿐 아니라 관상동맥질환, 뇌 졸중 등을 오히려 증가시킨다는 보고를 통하여 호르몬요법의 위험성을 경고하였다[7,36]. 이렇듯 삶의 질을 개선하기 위한 노력으로 갱년기 여성의 호르몬 보충 요법에 대한 관심이 높 아 지고는 있으나, 자궁내막암과 유방암, 심장 질환 등의 위험 성으로 인하여 안전하고 효율적인 호르몬 대체 요법이 시대적 으로 요구되고 있는 실정이다.

해조류는 식이성 섬유소인 복합다당류를 다량 함유하고 있 을 뿐 아니라 여러 비타민과 무기질이 비교적 풍부하고 그 독특한 맛과 향기가 우수한 알칼리성 기호식품으로서 가치가 높다[34]. 또한 해조류는 소화율이 낮아서 열량 원으로써의 가 치는 적지만 섬유성 식품으로 위에 포만감과 통변을 조절하는 효과[20,25]뿐만 아니라 항암[4,17], 항당뇨[19,21] 항고지혈증 [14,11], 항산화[5,30] 및 항노화[12] 등 여러 생리적 효능을 지 니고 있다. 우리나라 울릉도 부근에 주로 분포되어 있는 대황 (Eisenia bicyclis)은 다시마목(Laminariales) 미역과(Alariaceae) 에 속하는 다년생 식물로 연안 수심 $10 \mathrm{~m}$ 내외에서 서식하고 있으며, 줄기는 원기둥 모양이고 뿌리는 수지상이며 길이는 $1 \sim 2 \mathrm{~m}$ 에 달하며 지름은 2 3 cm로 중앙부가 좀 굵고 실질이다 
[24]. 대황은 다른 갈조류의 알긴산이나 fucoidan과 달리 함황 당류인 laminaran을 함유하고 있으며, 대황 성분들의 항고지 혈증[10,15], 항산화 및 항당뇨 기능도[2] 보고된 바 있다. 최근 일본에서는 기능성 신소재로 각광을 받고 있으나 국내에서는 아직까지 대황의 기능성 성분 및 이를 이용한 가공식품의 개 발에 관한 연구는 미비한 실정이다.

여성의 생식기계 질환을 치료할 목적으로 시행되는 난소절 제술은 에스트로겐의 생성을 저하시켜서 인위적인 폐경을 야 기하므로 골다공증뿐만 아니라 심혈관계질환 등의 연구에서 도 광범위하게 이용되고 있다[26]. 한편, 갱년기 장애를 유도하 였을 때 나타나는 estrogen 분비 감소로 인한 심혈관계 질환 발병 위험률에 대한 갈조류인 대황의 영향은 연구된 바가 없 다. 따라서 본 연구에서는 실험동물로써 흰쥐를 이용하여 인 위적으로 난소를 절제하여 갱년기 장애를 유도한 후, 대황 추 출물에 의한 혈 중 지질 함량 변화에 대한 효과를 검토하고자 하였다. 또한 동물실험에 이용하기 위한 추출물 제조 방법으 로는 열수와 에탄올을 이용하는 것이 일반적이므로, 이러한 추출 방법으로 추출물을 제조한 후 항산화 활성을 측정하여 활성이 우수한 추출물을 본 실험에 이용하고자 하였다.

\section{재료 및 방법}

\section{추출물의 제조}

본 실험에서 사용한 대황(Eisenia bicyclis)은 2010년 4월 울 릉도 해안일대에서 채취된 것을 울릉도몰에서 구입하여 물로 7 8회 씻어 염분과 불순물을 제거하고 동결 건조, 분쇄하여 실험에 사용하였다. 건조된 대황은 추출방법에 따른 최적 추 출조건을 선정하기 위해 각 건조된 시료 $100 \mathrm{~g}$ 을 $80 \%$ 에탄올 로 $80^{\circ} \mathrm{C}$ 에서 추출하였고, 동량의 증류수로 같은 방법으로 추 출하였다(Table 1). 위의 과정을 2회 반복하여 얻은 추출물을 감압 하에 건조하여, 각각의 폴리페놀 함량 및 $\mathrm{DPPH}$ radical scavenging 활성을 측정하였고, 동물실험은 체중 $\mathrm{kg}$ 당 투여 량 $1 \mathrm{ml}$ 중 에탄올 추출물을 $50 \mathrm{mg}$ 및 $200 \mathrm{mg}$ 되도록 용해하 여 사용하였다.

\section{총 폴리페놀 함량 측정}

총 페놀함량은 Folin-Denis법(1)으로 측정하였다. 시료 $1 \mathrm{ml}$ 에 $95 \%$ 에탄올 $1 \mathrm{ml}$, 정제수 $5 \mathrm{ml}$ 및 50\% Folin-Ciocalteu reagent (Sigma) $0.5 \mathrm{ml}$ 을 혼합하여 5 분간 방치한 후, $5 \%$ $\mathrm{Na}_{2} \mathrm{CO}_{3} 1 \mathrm{ml}$ 를 첨가하여 교반한 다음 1시간 동안 암소에 둔 후 catechin을 표준시약으로 사용하여 $725 \mathrm{~nm}$ 에서 흡광도를
측정하였다.

\section{항산화활성 측정(1,1-Diphenyl-2-picrylhydrazyl $\quad(\mathrm{DPPH})$ 라디칼 소거능 측정)}

추출물의 시료를 제조한 후에 96-well plate에 실험군과 blank에 추출물을 농도별 $(500,100,50,25,10 \mu \mathrm{g} / \mathrm{ml})$ 로 100 lㅣㅣㄱ 각각 6개씩 seeding한 다음 실험군에는 $60 \mu \mathrm{M} \mathrm{DPPH}$ $100 \mu 1$ 를 첨가하였다. 또한 control에는 추출물 대신에 $\mathrm{MeOH}$ $100 \mu 1$ 를 seeding한 다음 DPPH $100 \mu 1$ 를 첨가하고 blank에는 $\mathrm{DPPH}$ 대신에 $\mathrm{EtOH} 100 \mu 1$ 를 첨가하였다. 실온에서 30 분을 방치한 후 $540 \mathrm{~nm}$ 에서 microplate reader로 흡광도를 측정하 여 $\mathrm{DPPH}$ 의 환원에 의한 흡광도를 조사하였다. 대조군은 기존 의 항산화제인 L-ascorbic acid와 비교 하였다. 시료 첨가구와 대조군의 흡광도차를 백분율로 표시하였다. DPPH radical 저 해율은 아래 계산식에 따라 나타내었다.

DPPH radicals scavenging activity $(\%)=(1-\mathrm{A} / \mathrm{B}) \times 100$
A: Absorbance of sample
B: Absorbance of blank

\section{실험동물}

실험동물은 체중이 200-205 $\mathrm{g}$ 인 7주령의 암컷(SpragueDawley) 쥐 40마리를 (주)오리엔트바이오에서 분양 받아 1주 일간 적응시킨 후, 난소절제 수술(ovariectomy)을 하였고 비 난소절제 대조군에게는 sham-operation을 실시하였다. 수술 후 1 주일간 고형 사료를 주어 상처가 회복되면, 난괴법 (randomized complete block design)에 의해 군을 나누었다. 즉 실험동물은 비 난소절제 대조군(SHAM), 난소절제 대조군 (OVX-CON), 난소절제 후 대황 추출물 $50 \mathrm{mg} / \mathrm{kg}$ 투여군 (OVX-EB50), 난소절제 후 대황 추출물 $200 \mathrm{mg} / \mathrm{kg}$ 투여군 (OVX-EB200)으로 각 10마리씩 4군으로 나누어 $1 \mathrm{ml}$ 의 시료를 매일 경구 투여하며, 6 주간 사육하였다. 실험기간 동안 식이 섭취량과 체중은 매일 일정한 시간에 측정하였다. 동물실험실 의 사육조건은 온도 $24 \pm 2{ }^{\circ} \mathrm{C}$, 습도 $50-55 \%$ 를 유지시켰고, 물과 식이는 제한을 두지 않고 제공하였으며, 실험 시료는 증류수 로 용해하거나 현탁시켜 대조군은 동일 용량의 증류수를 투여 하였다.

\section{난소절제시술}

1 주일 동안 주위환경에 적응시켜 체중에 따라 난괴법에 의해 군을 나누어 난소절제 수술을 실시하였다. 수술은 에테 르로 마취하여 심마취기에 이르면 복부를 절개하여 난소를

Table 1. Extraction conditions of Eisenia bicyclis

\begin{tabular}{ccccc}
\hline Samples & Temperature $\left({ }^{\circ} \mathrm{C}\right)$ & Time (hour) & Solvent & Repetition \\
\hline \hline $\mathrm{H}_{2} \mathrm{O}$ ex. & 80 & 4 & distilled water & 2 \\
EtOH ex. & 80 & 4 & $80 \%$ ethanol & 2 \\
\hline
\end{tabular}


제거하고 절개부는 봉합하였다. 수술 후 일주일간 일반 식이 로 상처를 회복시킨 후 각 추출물 시료를 증류수에 용해하여 경구 투여하였다. 또한 대조군 설정을 위하여 비 난소절제군 은 복막 절개까지 난소절제 수술과 같은 방법으로 시행하고, 양측의 난소를 노출 하였다가 절제하지 않고 복막 속으로 다 시 넣어 난소절제와 같은 스트레스를 주고 다시 봉합하는 모 의수술(sham operation)을 시행하여, 이들을 대조군으로 사 용하였다.

\section{혈액 채취}

혈액은 실험동물을 해부 전 24시간 절식시킨 후 에테르 마 취 하에 개복한 후 복대동맥에서 채취하여 혈류 측정을 위해 헤 파린 처리된 튜브를 사용하고, 혈 액응고 실험을 위해 $3.2 \%$ sodium citrate를 1:9의 비율로 혼합하여 분석에 사용하였다. 또한 혈액의 생화학적 분석을 위해 상온에서 30 분간 방치 한 후, $3,000 \mathrm{rpm}$ 에서 10 분간 원심 분리하여 혈청을 분리하여 사 용하였다.

\section{혈청 중의 지질농도 분석}

혈청 중 중성지방, 총 콜레스테롤, $\mathrm{HDL}-$ 콜레스테롤 농도는 자동 측정용 slide (FUJI FILM, JAPAN)를 이용하여 Dry chemistry analyzer 3500i (Fuji, Japan)로 400 600 nm 파장에 서 측정하였다. 고밀도 지단백(HDL-cholesterol)의 경우 침전 제를 이용하여 유미지립(chylomicron), 저밀도 지단백(low density lipoprotein, LDL) 및 초저밀도 지단백(very low density lipoprotein, VLDL)을 침전시킨 후 상층액에 있는 HDL콜레스테롤을 측정하였다. LDL-콜레스테롤은 Friedewald 공 식에 의해 산출하였다. 또한 심혈관질환의 위험도 판정에 이 용되는 동맥경화지수(atherogenic index)와 심혈관위험지수 (cardiac risk factor)는 다음 공식을 이용하였다.

- LDL cholesterol=\{total cholesterol - (HDL-cholesterol triglyceride/5)\}

- AI (atherosclerotic index)=(total cholesterol - HDL-cholesterol)/HDL-cholesterol

- CRF (cardiac risk factor)=total cholesterol/HDL-cholesterol

\section{혈류 측정}

혈류 측정은 전혈을 사용 하였고, 채취한 혈액을 헤파린 처 리된 튜브를 사용하여 응고를 방지한 후, Micro Channel Array Flow Analyzer KH-6 (MC Lab, Japan)을 이용하여 채 취한 혈액 $100 \mu \mathrm{l}$ 를 주입하여 측정하였다.

\section{항혈전 활성 측정}

Ether 마취 후 개복하여 대동맥으로부터 채혈하여 $3.2 \%$ sodium citrate 용액과 1:9의 비율로 혼합한 뒤 $1,100 \mathrm{rpm}$ 에서
10 분간 원심분리하여 상층의 PRP (platelet rich plasma)를 취 하고, $3,000 \mathrm{rpm}$ 에서 10 분간 더 원심분리하여 상층에 혈장을 제거한 후 EDTA를 포함하는 washing buffer $(138 \mathrm{mM} \mathrm{NaCl}$, $2.7 \mathrm{mM} \mathrm{KCl}, 12 \mathrm{mM} \mathrm{NaHCO}$, $0.36 \mathrm{mM} \mathrm{NaH}_{2} \mathrm{PO}_{4}, 5.5 \mathrm{mM}$ glucose, $1 \mathrm{mM} \mathrm{EDTA}, \mathrm{pH}$ 6.5) $5 \mathrm{ml}$ 를 가하고 섞어주어 혈소 판을 재 현탁 시켰다. 이 혈소판을 다시 $3,000 \mathrm{rpm}$ 에서 10 분간 원심분리 한 후, 세척액을 버리고 혈소판을 위의 방법으로 한 번 더 세척하였다. 세척 후 suspending buffer $(138 \mathrm{mM} \mathrm{NaCl}$, $2.7 \mathrm{mM} \mathrm{KCl}, 12 \mathrm{mM} \mathrm{NaHCO}, 0.36 \mathrm{mM} \mathrm{NaH}_{2} \mathrm{PO}_{4}, 5.5 \mathrm{mM}$ glucose, $0.49 \mathrm{mM} \mathrm{MgCl}$, $0.25 \%$ gelatin, $\mathrm{pH}$ 7.4)로 재 현탁 시켜 $3,000 \mathrm{rpm}$ 에서 10 분간 원심분리한 후 다시 suspending buffer로 현탁시켜 washed platelet을 조제하였다. Washed platelet는 suspending buffer로 희석하여 혈소판 수가 $5 \times 10^{8} / \mathrm{ml}$ 이 되도록 하였고, 응집유도제로 collagen을 $2.5 \mu \mathrm{l}$ 가하여 5분간 반응시켜, Whole blood lumi-aggregometer (Chrono-log, U.S.A)를 사용하여 $37^{\circ} \mathrm{C}$ 에서 혈소판 응집을 측 정하였다. 혈소판 응집에 작용하는 약물의 효과는 응집 저해 율과 slop, lag time, amplitude로 나타낼 수 있다. Slop은 반응 이 일어나기 시작할 때의 속도를 나타내며, lag time은 반응하 는 시간, amplitude는 최대 응집력을 나타낸다. 응집력은 반응 이 최종적으로 끝났을 때의 광학밀도를 나타낸다.

\section{통계처리}

연구결과 얻어진 자료를 SPSS (statistical package for social science, version 12.0) 통계 프로그램을 사용하여 하위그룹 각 각의 기술 통계치(mean, $\mathrm{SD}$ )를 산출하였다. 사후검증은 Tukey 방법을 적용하였다. 유의수준은 $p<0.05$ 수준으로 검증 하였다.

\section{결과 및 고찰}

\section{대황의 항산화 활성}

페놀성 화합물은 식물계에 널리 분포되어 있는 물질로 다양 한 구조와 분자량을 가지며 페놀성 화합물의 phenolic hydroxyl기가 단백질과 같은 거대분자와의 결합을 통해 항산화, 항암 및 항균 등의 생리기능을 가지는 것으로 알려져 있다[6]. 폴리페놀성 물질은 활성 프리라디칼(reactive free radical)에 수소원자를 제공하여 안정한 비라디칼(non-radical)을 만들어 줌으로써 항산화효과를 나타내며, 해조류 중의 polyphenol성 물질은 에스트로겐의 활성이 있는 것으로 보고된 바 있다 $[16,22]$. 폴리페놀 함량이 높은 추출 방법을 이용하는 것이 에 스트로겐의 활성이 높을 것으로 예상되어 용매에 따른 폴리페 놀 함량을 측정하였다(Table 2). 그 결과 대황의 열수 추출물보 다 에탄올 추출물에서 총 폴리페놀 함량이 높은 것으로 나타 났다.

한편, 항산화 물질의 가장 큰 특징적인 기작은 유리기와 반 
Table 2. The total polyphenol contents and DPPH radical scavenging activity of Eisenia bicyclis extracts

\begin{tabular}{lcc}
\hline Samples $^{*}$ & $\begin{array}{c}\text { Total polyphenol } \\
\text { contents }\end{array}$ & $\begin{array}{c}\text { DPPH radical } \\
\text { scavenging activity }\end{array}$ \\
\hline $\mathrm{H}_{2} \mathrm{O}$ ex. & $6.9 \pm 0.7$ & $32.5 \pm 1.8$ \\
EtOH ex. & $10.5 \pm 1.2$ & $55.9 \pm 2.0$ \\
Ascorbic acid & - & $79.8 \pm 2.6$ \\
\hline
\end{tabular}

*Sample concentrations for DPPH radical scavenging activity measurements were used $100 \mathrm{ug} / \mathrm{ml}$.

응하는 것으로 유리기 소거작용은 활성 라디칼에 전자를 공여 하여 식물중의 항산화 효과나 인체에 노화를 억제시키는 척도 로 이용된다. DPPH는 안정한 유리기로 cysteine, glutathione 과 같은 황 함유 아미노산과 ascorbic acid, aromatic amine (p-phenylenediamine, p-aminophenol) 등에 의해 환원되어 탈색되므로 다양한 천연소재로부터 항산화 물질을 검색하는 데 많이 이용되고 있다[13]. Ascorbic acid를 positive control 로 하여 $100 \mu \mathrm{g} / \mathrm{ml}$ 농도에서 대황 추출물의 DPPH 라디칼 소거 활성을 측정한 결과, 열수 추출물의 $32.5 \%$ 에 비해 에탄올 추출물에서 $55.9 \%$ 의 높은 활성이 나타났다. 대조군인 ascorbic acid 의 $80.2 \%$ 보다 낮은 활성을 나타내고 있으나, 단일 물질이 아닌 ethanol 추출물임을 감안한다면 대황 에탄올 추출물의 항산화 활성은 매우 유용한 것으로 판단된다. 따라서, 총 폴리 페놀 함량이 높을 뿐만 아니라 항산화 활성도 더 높은 대황 에탄올 추출물을 동물 실험에 사용하였다.

\section{혈청 중 중성지방 및 총 콜레스테롤 함량}

혈중 콜레스테롤의 분포는 건강한 젊은 여성의 경우 같은 나이의 남성에 비해 총 콜레스테롤, LDL-콜레스테롤 그리고 중성지방은 낮고, HDL-콜레스테롤은 남성에 비해 상대적으 로 높다. 그러나 여성이 폐경에 이르게 되면 중성지방과 $\mathrm{HDL}-$ 콜레스테롤은 대체로 변화가 없으나, 총 콜레스테롤 및 LDL콜레스테롤은 증가되어 폐경기 이후 혈관 관련 질환의 발병률 이 높아지는 원인으로 작용하고 있다[3].
Table 3. Effect of Eisenia bicyclis ethanol extracts on serum total cholesterol and triglyceride in ovariectomized rats

$(\mathrm{mg} / \mathrm{dl})$

\begin{tabular}{lcl}
\hline Groups $^{1)}$ & T-CHO & \multicolumn{1}{c}{ TG } \\
\hline SHAM & $98.13 \pm 15.94^{\left.2)^{* 3}\right)}$ & $36.63 \pm 11.70^{*}$ \\
OVX-CON & $136.89 \pm 16.27$ & $51.22 \pm 12.43$ \\
OVX-EB50 & $131.40 \pm 23.71$ & $44.80 \pm 7.81$ \\
OVX-EB200 & $118.47 \pm 11.99$ & $41.16 \pm 9.42^{*}$ \\
\hline
\end{tabular}

${ }^{1)}$ SHAM, operated rats; OVX-CON, ovariectomized rats; OVX-EB50, ovariectomized rats supplemented Eisenia bicyclis ethanol extract $50 \mathrm{mg} / \mathrm{kg}$ bw/day; OVX-EB200, ovariectomized rats supplemented Eisenia bicyclis ethanol extract 200 $\mathrm{mg} / \mathrm{kg}$ bw/day.

${ }^{2)}$ The results are mean \pm SD for 10 rats in each group.

$\left.{ }^{3}\right)^{*} p<0.05$, significantly different from OVX-CON group

대황 추출물이 난소절제 흰 쥐의 혈청 중 중성지방과 총 콜레스테롤 함량에 미치는 변화를 Table 3에 나타내었다. 혈청 내 총 콜레스테롤의 경우 난소절제군(OVX-CON)이 비 난소 절제 대조군(SHAM)군과 비교해 유의적으로 증가하였으며, 이에 반해 난소 절제 후 대황 추출물의 투여에 의해 감소하였 다. Starzec와 Berger 등은 난소절제가 혈장 콜레스테롤을 증 가시켰다고 보고하였고[32], 난소절제에 의한 에스트로겐 수 준저하는 lipoprotein lipase (LPL)과 lecithin:cholesterol acyltransferase (LCAT)를 활성화시켜 LDL-콜레스테롤 합성을 증 가시킴으로써 혈중 콜레스테롤을 증가시키는 것으로 알려져 있다[35]. 한편, 혈청 중의 중성 지질 함량 또한 난소절제에 의해 증가하였으나 난소 절제 후 대황 추출물 투여로 감소하 였다. 특히 체중 $\mathrm{kg}$ 당 $200 \mathrm{mg} /$ day 투여한 OVX-EB200군에서 는 OVX-CON군에 비해 유의적으로 감소하는 결과를 나타내 었다.

혈청 중 $\mathrm{HDL}$-콜레스테롤, $\mathrm{LDL}-$ 콜레스테롤, 동맥경화지수 및 심혈관 위험 지수

혈청 중의 HDL-콜레스테롤의 농도는 난소절제로 인해

Table 4. Effect of Eisenia bicyclis ethanol extracts on serum HDL-cholesterol, LDL-cholesterol, atherogenic index (AI) and cardiac risk factor $(\mathrm{CRF})$ in ovariectomized rats

\begin{tabular}{lcccc}
\hline \multirow{2}{*}{ Groups $^{1)}$} & \multicolumn{2}{c}{ Cholesterol $(\mathrm{mg} / \mathrm{dl})$} & \multirow{2}{*}{$\mathrm{AI}^{3)}$} & CRF $^{4)}$ \\
\cline { 2 - 3 } SHAM & HDL & $39.30 \pm 16.24^{*}$ & $0.52 \pm 0.30^{*}$ & $1.52 \pm 0.28^{*}$ \\
OVX-CON & $\left.65.75 \pm 9.78^{5)^{*}}\right)$ & $77.02 \pm 21.65$ & $0.99 \pm 0.44$ & $1.99 \pm 0.44$ \\
OVX-EB50 & $70.11 \pm 8.24$ & $63.76 \pm 15.42$ & $0.71 \pm 0.13^{*}$ & $1.71 \pm 0.13^{*}$ \\
OVX-EB200 & $76.60 \pm 10.29^{*}$ & $56.18 \pm 11.29^{*}$ & $0.69 \pm 0.15^{*}$ & $1.69 \pm 0.15^{*}$ \\
\hline
\end{tabular}

${ }^{1)}$ Same as in Table 3.

${ }^{2}$ LDL cholesterol= $=$ total cholesterol-(HDL-cholesterol - triglyceride/5) $\}$.

${ }^{3)} \mathrm{AI}$ (atherogenic index $)=($ total cholesterol - HDL-cholesterol $) /$ HDL-cholesterol.

${ }^{4)} \mathrm{CRF}$ (cardiac risk factor)=total cholesterol/HDL-cholesterol.

${ }^{5)}$ The results are mean \pm SD for 10 rats in each group.

$\left.{ }^{6}\right)^{*}<<0.05$, significantly different from OVX-CON group. 
OVX-CON군이 SHAM군에 비해 증가하는 결과를 나타내었 다. 대황 추출물 투여군의 경우 체중 $\mathrm{kg}$ 당 $50 \mathrm{mg} /$ day 투여한 OVX-EB50군에서 OVX-CON군과 비교하여 유의적으로 증가 하는 결과를 나타내었다(Table 4). LDL-콜레스테롤 함량은 난 소절제로 인해 OVX-CON군이 SHAM군에 비해 증가되었으 나, 대황 추출물의 투여로 인해 OVX-ES200군에서 유의적으로 감소하였다. 이는 대황 추출물이 에스트로겐 유사활성을 나타 내어 혈 중 지질함량을 개선하는 것으로 사료된다. 총 콜레스 테롤과 HDL-콜레스테롤의 수치로 계산한 동맥경화지수(AI) 와 심혈관위험지수(CRF)는 일반적으로 동맥경화 및 순환기계 질환의 발병의 위험도를 알리는 위험지수로서 널리 이용되고 있다[28]. $\mathrm{AI}$ 와 $\mathrm{CRF}$ 는 난소를 절제한 $\mathrm{OVX}-\mathrm{CON}$ 군이 난소를 절제하지 않은 $\mathrm{SHAM}$ 군 보다 유의적으로 증가하는 결과가 나타났으나, 대황 추출물의 투여에 의해 유의적으로 감소하였 다. 따라서 이상과 같이 대황 추출물이 혈중 LDL-콜레스테롤 및 동맥경화 및 심혈관 위험 지수인 $\mathrm{AI}$ 와 $\mathrm{CRF}$ 의 감소시키는 결과로부터 심혈관 질환의 위험율을 저하시킬 수 있는 소재가 될 것으로 기대가 되나, 앞으로 구체적인 투여량의 범위 및 조절 등의 구체적인 연구가 요구된다.

\section{혈소판 응집에 미치는 영향}

최근에 폐경기 여성의 예방 및 치료 목적으로 여성 호르몬 치료가 정맥 혈전색증과 폐색전증의 발생을 증가시키는 것으 로 보고되고 있다[9,29]. 이는 여성호르몬이 혈액 응고와 관련 하여 섬유소 용해를 촉진시키고 플라스미노겐 활성 억제제인 palsminogen activator inhibitor-1을 감소시켜 이롭게 작용하 지만 이와는 독립적인 경로로 혈액응고를 활성화시키는 작용 이 있는 것으로 역효과를 보이고 있는 것이다[37]. 병적 상태나 기계적 손상 및 여러 화학물질 등에 의해 혈관 벽이 손상 받게 되면 혈관의 subendothelium에 collagen이 노출되어 여기에 혈소판이 점착하게 된다. 점착된 혈소판은 $\mathrm{ADP}$, thrombin 및 $\mathrm{Ca}^{+1}$ 등을 유리하고 5-HT와 $\mathrm{TxA}_{2}$ 를 생성하여 주위의 혈소판을 활성화 시켜 응집하게 된다. 이렇게 생긴 응집물(aggregate)이 혈류에 의해 떨어져 나간 것을 혈전(thrombus)이라 하고, 혈전 은 혈류를 따라 흐르다가 미세혈관을 막아 심근경색, 허혈 등 의 혈행 장애를 유발하게 된다[8]. 대황 추출물이 난소를 절제
한 흰 쥐의 항 혈전능에 미치는 영향을 검토하기 위해 난소절 제로 인하여 혈 중 지질 함량이 증가한 상태에서 washed platelet을 분리하고 콜라겐 $2 \mu \mathrm{g}$ 으로 혈소판 응집을 유도하였다. 그 결과 대황 추출물을 투여한 군이 OVX-CON군에 비해 혈소 판 응집을 억제하는 것으로 나타났다(Table 5). Amplitude (\%) 는 각 실험동물의 혈액에서 정제된 혈소판만을 분리하여 여기 에 콜라겐 $2 \mu \mathrm{g} / \mathrm{ml}$ 을 넣었을 때 일어나는 최대 응집 정도를 나타내는 것으로, 난소절제를 한 OVX-CON군이 난소절제를 하지 않은 SHAM군과 비교하여 증가하였으나, 대황 추출물 투여군인 OVX-EB50 및 OVX-EB200군 모두에서 감소하는 경 향을 나타내었다. Slop $(\Omega / \mathrm{min})$ 은 응집 유도물질인 콜라겐을 넣은 직후부터 1 분 동안의 응집곡선의 기울기를 말하며 혈소 판의 콜라겐에 대한 민감성을 나타내는 것으로써, 응집의 진 행과 함께 혈소판이 platinum electrodes에 부착됨으로써 발 생하는 전기저항(impedance: $\Omega$ )의 크기를 혈소판 응집치로 나타낸다. 난소절제로 인해 OVX-CON군이 비 난소절제군인 SHAM군과 비교하여 Slop이 증가하여 혈소판 응집이 촉진되 었으나, 대황 추출물 투여에 의해 감소하였고 특히 OVX-EB50 군에서 유의적으로 감소하여 혈소판 응집이 억제되었다. 응집 시간을 나타내는 lag time (sec)은 난소절제에 의해 반응이 일 어나는 시간이 짧아져, 혈소판 응집이 촉진되는 결과가 나타 났다. 이에 반해 대황 추출물 투여군인 OVX-EB50 및 OVX-EB200군에서 응집시간이 지연되었으며, 특히 OVX-EB200군의 경우 정상군인 SHAM군과 같은 응집지연 효 과를 보였다. 이상의 결과로부터 대황 추출물이 난소절제로 인한 혈소판 응집 억제 효과를 나타내어 혈관 관련성 질환에 효과가 있을 것으로 기대된다.

\section{혈류 개선 효과}

에스트로겐의 결핍으로 인해 여러 요인들이 작용하여 여성 의 동맥경화, 심근경색 등 심혈관계 질환이 증가되는데, 이런 심혈관계 질환은 혈관의 동맥경화와 혈액의 유동성의 저하로 부터 발생되는 것으로 알려져 있다[33]. 특히, 혈액의 점도가 그 유동성을 조절하는 중요한 인자로서, 혈장의 점도, 헤마토 크립트, 적혈구 변형, 적혈구의 결함 등이 있다. 혈장의 점도는 fibrinogen, globulin 등의 분자량의 크기 및 콜레스테롤 등의

Table 5. Effect of Eisenia bicyclis ethanol extracts against collagen induced platelet aggregation

\begin{tabular}{lccc}
\hline Groups $^{1)}$ & Amplitude $(\%)$ & Slop $(\Omega / \mathrm{min})^{3)}$ & Lag time $(\mathrm{sec})$ \\
\hline SHAM & $\left.67.83 \pm 9.13^{2)^{*}}\right)$ & $107.6 \pm 9.84^{*}$ & $0: 24 \pm 0: 09$ \\
OVX-CON & $85.38 \pm 9.01$ & $124.02 \pm 21.34$ & $0: 19 \pm 0: 04$ \\
OVX-EB50 & $73.52 \pm 13.03$ & $102.43 \pm 14.51^{*}$ & $0: 21 \pm 0: 05$ \\
OVX-EB200 & $73.33 \pm 9.94$ & $115.6 \pm 11.54$ & $0: 24 \pm 0: 05$ \\
\hline
\end{tabular}

\footnotetext{
${ }^{1)}$ Same as in Table 3.

${ }^{2)}$ The results are mean \pm SD for 10 rats in each group.

${ }^{3)}$ Initial slope is ohm change for the first on minute.

${ }^{4)^{*}} \mathrm{p}<0.05$, significantly different from OVX-CON group.
} 


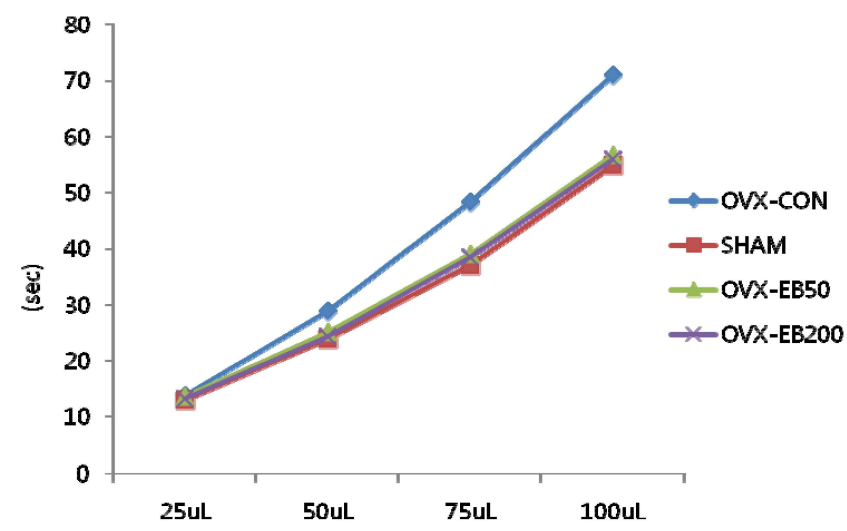

Fig. 1. Effect of Eisenia bicyclis ethanol extracts on micro channel array in ovariectomized rats.

지질 및 glucose 등에 영향을 받는다[18]. 혈액의 유동성에 미 치는 대황 추출물의 영향을 검토하기 위해 SHAM, OVXCON, OVX-EB50, OVX-EB200군의 혈액을 각각 채취하여 항 응고제인 헤파린 처리 후, 일정한 압력으로 인해 혈액이 모세 관을 $25,50,75,100 \mu \mathrm{l}$ 통과하는 시간을 Micro channel array flow analyzer (MC-FAN)를 이용하여 측정하였다. Fig. 1은 대황 추출물이 난소를 절제한 흰 쥐의 혈액 유동성에 미치는 영향을 나타낸 것이다. 초기의 $25 \mu \mathrm{l}$ 주입 시 각 군간의 별 다른 차이를 보이지 않았으나, $50 \mu \mathrm{l}$ 을 주입하였을 경우 $\mathrm{SHAM}$ 군이 OVX-CON군에 비해 빠른 시간에 모세관을 통과 하였고 주입량이 증가할수록 모세관 통과 시간은 차이가 났 다. 대황 추출물 투여군의 경우 OVX-CON군보다 빠른 시간에 통과하였고 SHAM군과 비슷한 혈액 유동성을 나타내어 대황 추출물이 혈류 개선에도 효과가 있을 것으로 사료된다.

\section{References}

1. AOAC. 2005. Official Method of Analysis. 18th eds. Association of Official Analytical Chemists, Washington DC, USA. Vol 45, pp. 21-22.

2. Cahyana, A. H., Shoto, Y. and Kinoshita, Y. 1992. Pyropheophytin as an antioxidative substance from the marine alga, Arame(Eisenia bicyclis). Biosci. Biotech Biochem 56, 1533-1535.

3. Campos, H., Wilson, P. W. F., Jimenez, D., McNamara, J. R., Ordovas, J. and Schaefer, E. J. 1990. Differences in apolipoproteins and low-density lipoprotein subfractions in postmenopausal women on and off estrogen therapy: Results from the Framingham Offspring Study. Metabolism 39, 1033-1038.

4. Cho, K. J., Lee, Y. S. and Ryu, B. H. 1990. Antitumor effect and immunology activity of seaweeds toward sarcoma-180. J. Korean Fish Soc. 23, 345-352.

5. Cho, S. H., Kang, S. E., Cho, J. Y., Kim, A. R., Park, S. M., Hong, Y. K. and Ahn, D. H. 2007. The antioxidant properties of brown seaweed (sargassum siliquastrum) extracts. J. Med Food 10, 479-485.

6. Choi, Y, M., Kim, H., Shin, J. J., Park, J. M. and Lee, J. 2003. The antioxidant activities of the some commercial teas. J. Korean Soc. Food Sci. Nutr. 32, 723-727.

7. Grady, D., Herrington, D., Bittner, V., Blumenthal, R., Davidson, M., Hlatky, M., Hsia, J., Hulley, S.A., Khan, H. S., Newby, L. K., Waters, D., Vittinghoff, E. and Wenger, N. 2002. Cardiovascular disease outcomes during 6.8 years of hormone therapy: heart and estrogen/progestin replacement study follow-up(HERS II). J. Am. Med. Assoc. 288, 4957-4963.

8. Hardisty, R. M. 1993. Platelets : receptors, adhesion, secretion. part B. (methods in enzymology, volume 215, issues 1-2) : edited by J.J. Hawiger, Academic Press; San Diego.

9. Hirofumi, T., Hiroake, S., Tatsuya, T., Mari, K. M., Yoshitaka, H. and Akira, T. 1997. Short-term estrogen augments both nitric oxide-mediated and non-nitric oxidiated endothelium-dependent forearm vasodilation in postmenopausal women J. Cardiovascular Pharmaco. 30, 481-488.

10. Jang, Y. H., Choi, S. W. and Cho, S. H. 2008. Effect of Eisenia bicyclis and its pillon serum lipid statusin ratsfed high fat diet. Korean J. Nutr. 41, 5-12.

11. Joo, D. S., Lee, J. K., Choi, Y. S., Cho, S. Y., Je, Y. K. and Choi, J. W. 2003. Effects of seatangle oligosaccharide drink on serum and hepatic lipids in rats fed a hyperlipidemic diet. J. Korean Soc. Food Sci. Nutr. 32, 1364-1369.

12. Kang, H. S., Kim, H. R., Byun, D. S., Son, B. W., Nam, T. J. and Choi, J. S. 2004. Tyrosinase inhibitors isolated from the edible brown alga Ecklonia stolonifera. Arch Pharm Res. 27, 1226-1232.

13. Kim, C. H., Youn, H. M., Jang, K. J., Song, C. H. and Ahn, C. B. 2004. Inhibitory Effect on NO, Scavenging Effect on DPPH Radical in Whallak-tang. J. Korean Acupuncture Moxibustion Society 21, 69-78

14. Kim, H. S. and Kim, G. A. 1998. Effects of the feeding Hijikia fusi-forme (Harvey) Okamura on lipid composition of serum in dietary hyperlipidemic rats. J. Korean Soc. Food Sci. Nutr. 27, 718-723.

15. Kim, Y. M., Han, C. K., Bang, S. J. and Park, J. H. 2006. Effect of laminaran from Eisenia bicyclis on serum lipids in rats fed high cholesterol diet. Korean Soc. Food Sci. Nutr. 36, 841-846.

16. Kim, Y. K. and Kim, M. H. 2010. Effect of Ecklonia stolonifera extracts on bone turnover markers in ovariectomized rats. J. Korean Soc. Food Sci. Nutr. 39, 1769-1775.

17. Kim, Y. M., Do, J. R., Kim, D. S. and Park, J. H. 2006. Cytotoxicities of hydrolyzed crude laminaran from Eisenia biscyclis on the SNU-1, Hela and SW cells. Korean Food Sci. Technol. 793-798.

18. Koji, S., Hiroyuki, S. and Masami, M. 2003. Study on blood rheology measured by MC-FAN. Rinsho Byoi. 51, 770-775.

19. Lee, H. S., Choi, M. S., Lee, Y. K., Park, S. H. and Kim, Y. J. 1996. A study on the development of high-fiber supplements for the diabetic patients (2)-Effect of seaweed supple- 
mentation on the lipid and glucose metabolism in streptozotocin-induced diabetic rats. J. Korean Soc. Food Sci .Nutr. 29, 296-306.

20. Lee, J. G., Lim, Y. S., Joo, D. S. and Joung, I. H. 2002. Effects of diet with seatangle (Kjellmaniella crassifolia) on calcium absorption, serum composition and feces in rats. J. Korean Fish Soc. 35, 601-607.

21. Lee, K. S., Se, J. S. and Choi, Y. S. 1998. Effect of sea tangle and hypoglycemic agent on lipid metabolism in diabetic rats. J. Korean Soc. Food Sci. Nutr. 27, 960-967.

22. Lee, S, Jang, M. K., Kim, N. Y., Jang, H. J., Lee, D. G., Kim, M. H., Kim, Y. Y., Kim, S. G., Yoo, B. H. and Lee, S. H. 2010. Verification of the fractions with strong estrogenic activities from brown algae. J. Life Sci. 20, 1807-1811.

23. Moore, A. O., Mullins, P. M. and Pugh, M. C. Hormonal replacement therapy. In; Dipiro JT, Talbert RL, Hayes PE, Yee GC, Matzke GR, Posey LM; Pharmacotherapy, A pathophy siological approach.

24. National Fisheries Research \& Development Institute, Information Center of Marine Biology Versality, bicyclis (Eisenia bicyclis) 2005.

25. Oh, H. K. and Lim, H. S. 2007. Effects of the products of raw sea tangle on chronic idiopathic constipation. J. Korean Soc. Food Sci. Nutr. 36, 720-726.

26. Okada, Y, Ishimaru, A., Suzuki, R. and Okuyama, T. 2004. A new phloroglucinol derivatives from the brown alga Eisenia bicyclis. Potential for the effectives from the brown alga Eisenia bicyclis. Postential for the effective treatment of diabet complication. J. Nat. Prod 67, 103-105.

27. Rosen, C, Bilezikian, J. P. 1997. Editorial : Evolving toward a new paradium for prevention of osteoporosis-The time is upon us. J. Clin. Endocrinol. Metab. 82, 2782-2783.

28. Rosenfeld, L. 1989. Early methods in the diagnosis of atherosclerosis. Lipoprotein Analysis 113, 1101-1110.

29. Rossouw, J. E., Anderson, G. L., Prentice, R. L., LaCroix, A. Z., Kooperberg, C. and Stefanick, M. L. 2002. Risks and benefits of estrogen plus progestin in healthy postmenopausal women: principal results from the Women's Health Initiative randomized controlled trial. JAMA 288, 321-333.

30. Ruberto, G., Baratta, M. T., Biondi, D. M. and Amico, V. 2001. Antioxidant activity of extracts of the marine algae genus Cystoseira in a micellar model system. J. Appl. Phycol. 13, 403-407.

31. Stampfer, M. H. and Colditz, G. A. 1991. Estrogen replacement therapy and coronary heart disease: a quantitative assessment of the epidemiologic evidence. Prev. Med 20, 47-63.

32. Starzec, J. J. and Berger, D. F. 1986. Effects of stress and ovariectomy on the plasma cholesterol, serum triglyceride, and aortic cholesterol levels of female rats. Physiol. Behav. 37, 99-104.

33. Sumino, H., Ichikawa, S., Takahashi, T., Sakamoto, H., Goto-Onozato, K., Koya, S., Kanda, T., Nara, M., Seki, K., Murakami, M. and Kurabayashi, M. 2006. Conjugated estrogen plus medroxyprogesterone does not impair blood rheological properties in hypertensive postmenopausal women. Maturitas 53, 306-314.

34. Sung, J. H., Ha, Y. S., Im, M. H., Im, J. G. and Kang, K. S. 2002. Seaweed and health In: Foods and Health pp. 190, Hyungseol Press Co, Seoul.

35. Wakatsuki, A. and Sagara, Y. 1995. Lipoprotein metabolism in postmenopausal and oophorectomized women. Obstet. Gynecol. 85, 523-528.

36. Writing group for the WHI investigators. 2002. Risks and benefits of estrogen plus progestin in healthy postmenopausal women: principal results from the women's health initiative randomized controlled trial. J. Am Med Assoc. 288, 321-333.

37. Yang, H. C., Sung, H. J., Na, K. S., Kwon, M. H. and Park, M. K. 1996. Screening of anticoagulant polysaccharides from edible plants. J. Korean Agricultural Chem Soci. 39, 159-164. 


\section{초록 : 대황 추출물의 in vitro 항산화 활성 및 난소를 절제한 흰쥐의 혈중 지질함량에 미치는 영향 박용수·김미향ㅊ \\ (신라대학교 의생명과학대학 식품영양학과)}

갱년기의 여성에는 여러 폐경 증후들이 나타나는데, 특히 에스트로겐의 감소로 인한 혈중의 지질 조성의 변화 등으로 심혈관계 질환의 발병율이 높아지게 된다. 이러한 폐경기의 문제를 감소시키기 위하여 호르몬 보충요법 이 사용되고 있으나 유방암, 관상동맥질환 등을 오히려 증가시키는 등의 보고가 있다. 따라서 해조류 중에서 갈조 류인 대황 추출물을 이용하여 갱년기 유도 흰쥐의 혈중지질 농도, 혈소판 응집력 및 혈액 유동성을 통하여 그 효과를 검토하고자 하였다. 또한 동물실험에 이용하기 위한 추출물 제조 방법으로는 열수와 에탄올을 이용하는 것이 일반적이므로, 이러한 추출 방법으로 추출물을 제조한 후 항산화 활성을 측정하여 활성이 우수한 추출물을 본 실험에 이용하고자 하였다. 실험 결과 갱년기 유도로 인하여 증가된 혈청 중 중성지방 및 총콜레스테롤 함량 은 대황 추출물 투여에 의해 저하되었으며, 특히 대황 추출물 $200 \mathrm{mg} / \mathrm{kg} \mathrm{bw} /$ day 투여는 중성지방 함량을 유의 적으로 감소시키는 결과를 나타내었다. $\mathrm{AI}$ 와 CRF는 난소를 절제한 OVX-CON군이 난소를 절제하지 않은 SHAM 군 보다 유의적으로 증가하는 결과가 나타났으나, 대황 추출물의 투여에 의해 유의적으로 감소하였다. 또한 대황 추출물의 항 혈전능에 미치는 영향을 검토하기 위해, 난소절제로 인하여 혈 중 지질 함량이 증가한 상태에서 washed platelet을 분리하고 콜라겐 $2 \mu \mathrm{g}$ 으로 혈소판 응집을 유도하였다. 그 결과 대황 추출물을 투여한 군이 OVX-CON군에 비해 혈소판 응집을 억제하는 것으로 나타났다(Table 5). Amplitude (\%)는 난소절제를 한 OVX-CON군이 난소절제를 하지 않은 SHAM군과 비교하여 증가하였으나, 대황 추출물 투여군인 OVX-EB50 및 OVX-EB200군 모두에서 감소하는 경향을 나타내었다. 난소절제로 인해 OVX-CON군이 비 난소절제군인 SHAM 군과 비교하여 Slop이 증가하여 혈소판 응집이 촉진되었으나, 대황 추출물 투여에 의해 감소하였고 특히 OVX-EB50군에서 유의적으로 감소하여 혈소판 응집이 억제되었다. 응집시간을 나타내는 lag time (sec)은 난소절 제에 의해 반응이 일어나는 시간이 짧아져, 혈소판 응집이 촉진되는 결과가 나타났다. 이에 반해 대황 추출물 투여군인 OVX-EB50 및 OVX-EB200군에서 응집시간이 지연되었으며, 특히 OVX-EB200군의 경우 정상군인 SHAM군과 같은 응집지연 효과를 보였다. 한편, 대황 추출물이 혈액의 유동성에 미치는 영향에 대한 실험 결과 난소절제에 의해 혈액의 점도가 증가하여 유동성이 저하되었으나, 대황 추출물 투여에 의해 유동성이 향상됨을 알 수 있었다. 따라서 대황 추출물이 외부자극으로 인한 혈소판 응집능이나, 점도의 증가로 인한 혈액의 유동성에 효과적인 것으로 보여진다. 따라서 이상과 같이 대황 추출물이 혈중 LDL-콜레스테롤, $\mathrm{AI}$ 및 $\mathrm{CRF}$ 를 감소시키고, 혈액 유동성을 증가시키는 결과로부터 심혈관 질환의 위험율을 저하시킬 수 있는 소재가 될 것으로 기대가 되나, 앞으로 투여량의 범위 및 조절 등의 구체적인 연구가 요구된다. 